Revue Française de Civilisation Britannique United Kingdom Since the Nineteenth Century

\title{
The 2011 Forestry Commission Fiasco: Political Roots, Cultural Ramifications
}

La crise de la Forestry Commission (2011) : racines politiques, ramifications culturelles

Sylvie Nail

\section{OpenEdition}

\section{Journals}

Electronic version

URL: http://journals.openedition.org/rfcb/2646

DOI: $10.4000 /$ rfcb. 2646

ISSN: 2429-4373

Publisher

CRECIB - Centre de recherche et d'études en civilisation britannique

Electronic reference

Sylvie Nail, «The 2011 Forestry Commission Fiasco: Political Roots, Cultural Ramifications », Revue

Française de Civilisation Britannique [Online], XXIII-3 | 2018, Online since 07 December 2018, connection on 24 April 2019. URL : http://journals.openedition.org/rfcb/2646 ; DOI : 10.4000/rfcb.2646

This text was automatically generated on 24 April 2019

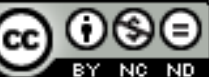

Revue française de civilisation britannique est mis à disposition selon les termes de la licence Creative Commons Attribution - Pas d'Utilisation Commerciale - Pas de Modification 4.0 International. 


\title{
The 2011 Forestry Commission Fiasco: Political Roots, Cultural Ramifications
}

\author{
La crise de la Forestry Commission (2011) : racines politiques, ramifications \\ culturelles
}

Sylvie Nail

Not only did William the Conqueror have the nerve
to, well, conquer, he also nicked our woods.
England had always been a paradise for trees,
covered from the end of the last ice age in
increasingly dense forests of oak, hazel and birch,
with some pine. When early islanders began
farming, the tree cover slowly began to give way to
pasture and cultivated land, but under Anglo-
Saxon kings, the forests still belonged to the
landowners and their subjects".

\section{Introduction}

Trees by their very nature encapsulate time and connect human beings to the past, the present and the future, as well as to human life cycles. ${ }^{2}$ The epigraph, from an article in the Guardian published in 2013, is typical of the present representation of English forests as cultural landscapes, that is, intentional as well as unintentional expressions of history, environment and cultural identity combined. To be fair, though, it is worth stating that before William the Conqueror set foot on the English coast of Sussex and committed the aforementioned crimes, the change in land use in the Roman and Anglo-Saxon times had taken their toll on wooded landscapes and the actual forest cover had dwindled to about $15 \%$ : in the $11^{\text {th }}$ century, England was already amongst the least wooded countries in North-West Europe. ${ }^{3}$ 
In spite of the fact that England continues to have a smaller percentage of its land covered in forests than most European countries (10\% of the total land area, according to Forestry Commission figures of 2017), ${ }^{4}$ forests play an important part in the collective psyche, as remnants of a landscape heritage and reminiscent of the rural past. ${ }^{5}$ The Guardian quotation thus testifies, first, to a contemporary streak of retrophilia, and then, to an association of the nation with its woodlands, which goes back to the 17th century. Additionally, forests have since the late 1990s become the object of an amazing array of initiatives, programmes, grant schemes and, above everything else, discourses repeating the copious academic literature on their multiple benefits for health and wellbeing, education and social cohesion. ${ }^{6}$ In $21^{\text {st }}$-century England, wooded spaces are thus seen by most, especially in urban areas, as emblematic of national identity, as well as refuges associated with the benefits of nature at large.

What happens when this supposedly consensual view is challenged by the resurgence of an alternative discourse based on the economic revenue forests should provide? It is such a conflict of views and interpretations that this article aims to analyse, based on the specific case of the 2011 Forestry Commission crisis.

The first part analyses the cultural services delivered through artistic activities in State forests, an unsung, but growing aspect of today's forestry. The rationale of the proposed privatisation is then presented. Lastly, thanks to the analysis of official documents, the press, the Forestry Commission's opinion surveys and the almost 7,500 responses to the public consultation in January and February 2011 , as well as interviews with professionals from the Forestry Commission and members of environmental organisations, the article shows why so many English people united behind the non-negotiable phrase 'Hands off my trees !' and paradoxically saved the State forestry service from the Government.

\section{Social Forestry, Culture and the arts}

Attempting to give an account of the numerous 'inspirational services' and wooded spaces would require to scan the fields of, at the very least, anthropology, philosophy, art history, literature and environmental psychology. Indeed, trees and woodland have inspired innumerable cultural and artistic expressions: books, films, photography, paintings, sculpture, among others. Woodlands can and do foster the imagination and artistic creativity by their very presence. Furthermore, artistic practices in woods can help reach objectives relating to the social, spiritual or heritage realms. Woodlands have thus become the focus of a growing, seldom explored, array of artistic practices over the last two decades.

In order to examine existing artistic practices in English forests and their underlying agenda, the focus will be on the State forests managed by the Forestry Commission. Arguably, these do not constitute the majority of woodlands: the Forestry Commission estate only represents $18 \%$ of England's total woodlands. ${ }^{8}$ Yet, State forests are particularly interesting to study because the Forestry Commission is most likely to 1 ) open its woodlands to the public (these $18 \%$ represent $44 \%$ of all accessible woods in England); 2) show responsiveness to the social aspects of forestry and have the staff to research and implement it; 3) connect artistic programmes with other governmental policies delivered by public bodies (National Health Service, Arts Council, local authorities, etc.). Indeed, the vast majority of the woodland sites where arts take place are on Forestry Commission land..$^{10}$ 
Why are the arts and forests good partners?

\section{The cultural dimension of 'ecosystem services'}

As natural ecosystems, forests provide multiple services on which human welfare depends. In 2005, under the auspices of the United Nations Environment Programme (UNEP), a comprehensive study of these 'ecosystem services' was published. They can be provisioning services, such as food and fuel wood; regulating services (regulation of water, climate or erosion) and cultural services, which can be summarised as the nonmaterial benefits that people obtain from ecosystems 'through aesthetic experience, reflection, recreation and spiritual enrichment'. ${ }^{11}$ The concept of ecosystem services thus encompasses economic, social, environmental and cultural dimensions and it has been widely used since 2005 as a basis for studies and policies. ${ }^{12}$ UNEP notes that "human cultures, knowledge systems, religions, and social interactions have been strongly influenced by ecosystems". ${ }^{13}$

One of the symptoms of the rising importance of cultural services in urban societies has been the development of what Alain Corbin calls "arboricultural tourism", ${ }^{14}$ referring to woodlands as venues for nature-based recreational activities, such as walking, birdwatching, camping, fishing, swimming, and the like, in a context of increased affluence and leisure time. The Third (Lisbon, 1998) and Fourth (Vienna 2003) Ministerial Conferences on the Protection of Forests in Europe (MCPFE) encouraged Europe's governments to integrate "all forest functions" 15 and stressed the social and cultural importance of forests in Europe: no longer a sideline of agriculture, multiple-use forestry has come to embrace a whole new agenda for the benefit of the population. In the wake of the Vienna MCPFE conference, a workshop took place in 2005 in order to elaborate on the third resolution, namely Preserving and Enhancing the Social and Cultural Dimensions of Sustainable Forest Management in Europe $e^{\text {through the }}$ ongoing elaboration of indicators of cultural and spiritual values by country. Artistic practices in woodland settings are one mode of expression likely to contribute to these cultural services. ${ }^{16}$

\section{Taking the arts on board in the Forestry Commission}

In this context, in the UK, following the publication of the UNEP report and the subsequent House of Commons Environmental Audit Select Committee report, ${ }^{17}$ "ecosystem services" has become a catchphrase in forestry. It looks as though the less important the economic dimension of forestry becomes, the more other ecosystem services rise to prominence, a feature which UK forestry shares with other industrial countries. ${ }^{18}$ In that sense, the Forestry Commission's arts activities

add in unique ways to people's awareness, understanding and valuing of trees, forests and woodland. They can be effective in addressing intangible values such as sense of place, cultural history and identity; and they help with reassessing the relationship between nature and society, and in rebuilding some of the lost connections. $^{19}$

It seems to be a two-way relationship: artistic practices provide benefits for the knowledge of woodlands, while wooded landscapes develop artistic awareness. For the first time in such emphatic terms, the Forestry Commission Strategy for England (2007) underlined these values as of being of the greatest concern for forestry strategies: 
woodlands enhance people's lives, health and well-being in all sorts of ways - with birdsong, seasonal colour, giving dimension to the view in low-lying landscapes and providing opportunities for exercise and recreation. They offer people an escape from urban streets and a link with historical times. ${ }^{20}$

As a consequence, out of the five priorities presented in the Strategy, three address human benefits, ${ }^{21}$ mostly under the heading Communities and Places. Additionally, through its advice and subsidies mechanism, the Forestry Commission can help private woodland owners to implement such policies on their lands too.

\section{Stakes and forms of artistic practices in English forests}

Examples and case studies of artistic practices undertaken under the auspices of the Forestry Commission are numerous, but scattered in various documents and in specific publications dedicated to local and regional arts strategies. Indeed, the Forestry Commission's arts policies have not, so far, been embedded into one document or present across the width and breadth of the organization. The main reason for this is that many of the existing programmes and initiatives are of a bottom-up nature, brought about at the grass roots level under the impetus of one or more members of staff as opposed to being coordinated by the institution. ${ }^{22}$

In this context, the first national overview of artistic activities in the Forestry Commission estate, produced by an independent researcher, was of particular interest. ${ }^{23}$ The author's second report, published in 2010, noted a greater democratisation of the arts in the last twenty years, in the sense of a move away from "the aesthetic formalism of outdoor public sculpture and 'land art', [...] to more engaged investigation of issues through art based on projects, processes, interactions and concepts". ${ }^{24}$

Thus, over the past decade, the arts have come into their own within forest policies, at least in theory and from an institutional point of view. Woodland elicits certain types of reactions likely to trigger off the imagination and creativity necessary to produce artworks, the output being either art for art's sake in propitious settings or social forestry providing ecosystem services. Indeed,

arts initiatives undertaken in partnership with, or under the auspices of the Forestry Commission, are making significant contributions to objectives relating to education, awareness, social inclusion, sense of place/identity, creative enterprise, cultural expression, physical and mental well-being, environmental valuation, recreation and amenity, community cohesion, and local economies; in addition to producing art that is of intrinsic value for its own sake. ${ }^{25}$

Arguably, the two outputs are often interconnected: "the distinction between 'in the forest' and 'of the forest' is probably best seen as a continuum". ${ }^{26}$ For the sake of clarity, however, we shall first present artistic practices designed to foster imaginative and spiritual qualities before turning to forest-based art activities related to social and cultural objectives.

Forests provide a sense of place, a feeling of permanence and stability, and they contribute to foster inspiration and spiritual values, understood as "standards for judging meaning". ${ }^{27}$ Artists enjoy these environments, where the imagination can be opened up without the physical boundaries and constraints of galleries, thus promoting different relationships and aesthetics. ${ }^{28}$

The use of these inspiring settings for the arts has developed over the last decades, starting on a significant scale in the 1970s in the Yorkshire Sculpture Park and in Grizedale Forest (Cumbria), which were at the forefront of the development of art in the 
environment, in the form of outdoor sculpture. Indeed, the Forestry Commission arts programmes "foregrounded a generation of land artists or environmental artists such as David Nash, Andy Goldsworthy and Sally Matthews, who worked outdoors with natural and found materials and with aesthetic concerns rooted in the natural environment itself' ${ }^{29}$ It is thus fitting that Grizedale Forest Park, home to the largest permanent collection of sitespecific art in the environment in the UK, should have become the first Forestry Commission site to appoint an Arts Development Officer (later Arts Curator) in Britain in 2010. Her role, as well as developing the sculpture programme and fundraising, involves working with the community outreach ranger and the education team "to establish closer links with the local community, by widening participation in the arts and access to the forest". ${ }^{30}$

Another outstanding example since its inception in 1993 is Stour Valley Arts (SVA), an environmental public art project based at King's Wood (Kent). It aims at developing recreation and at arousing the public's interest towards contemporary art within the natural and historical context of an ancient woodland setting. Thus, SVA invites artists to undertake commissions, using natural materials. These artworks "are accessible to visitors, appeal to their senses, and inspire reflection on the perennial themes of time, place, life, decay and regeneration". ${ }^{31}$

The Forestry Commission forests are increasingly being used for artistic events open to the public, including, among others, sound and light events, storytelling, creative writing, concerts, drama, workshops on photography, sculpture, drawing and painting, as well as art-related conferences. ${ }^{32}$

On top of being good places for artists to give free rein to their creative imagination, state forests also serve social policies through artistic practices, within the framework of their recreational function..$^{33}$ Indeed, the message that emerged most strongly from the call for views in 2011 was how important access to woods and forests, and particularly to the public forest estate, is for people's well-being and enjoyment of the natural world. ${ }^{34}$ Giving a full account of artistic initiatives connected to social forestry is impossible here, so only three particularly representative realms (health, education and the environment) will be presented briefly, to show how artistic practices respond and contribute to public policy agendas.

In 2007, the Department of Health and the Arts Council jointly published two documents emphasising the importance of the arts in reaching health objectives. The first one provided "the framework of Arts Council England's first formal national strategy for arts and health" ${ }_{35}$ while the second one celebrated "the benefits of the arts in improving everyone's wellbeing, health and healthcare, and its role in supporting those who work in and with the Health Service". ${ }^{36}$ Although the Forestry Commission or forests are not mentioned in these publications, the promotion of health through artistic practices has been the object of possibly the first form of art to be found in the Forestry Commission forests - the sculpture trail. Using the arts as vector, these trails entice people to discover sculptures along a route, while exercising at the same time. Such examples can now be found up and down the country, as part of the 'Active Woods' campaign for instance. Thus, the Ridding Wood Trail, the most popular walk in Grizedale Forest, was designed as an accessible public sculpture trail in 1990. Other famous examples include the award-winning Route to Health Arts Trail in Cannock Chase Forest (Staffordshire), a one-mile trail displaying art works made by individuals and local groups alongside artists, which involves the Primary Care Trust, the Cannock Chase District Council and the Forestry Commission and has permitted to sensitise local populations to health issues while generating immense 
support for the arts activities. The number of visitors to the forest has been multiplied by ten as a consequence of the interest generated in the artworks. ${ }^{37}$

Although the physical health benefits may be more obvious, it is the contribution of forests to mental well-being which actually appears to dominate public expressions of the value of woodlands: they help people de-stress, slow the heartbeat, lower blood pressure and thus help improve mental well-being. ${ }^{38}$ The arts may thus help promote the Government's agenda on health, while participating in these sculpture trails helps local environmental artists to become better-known.

Education lies at the heart of many artistic programmes in woodlands. An emblematic case is to be found in the more than 100 Forest School sites in England, where children learn both about the environment and other subjects relevant to the various key stages of their curriculum. Education out of doors is often seen as a means to help reengage children who may have difficulty in a normal classroom setting. The added mediation of the arts (music, literature, design, drawing and painting) helps to present natural settings differently to children whose connections with nature may have been lost. Working with environmental artists, children learn about pattern, colour, texture, sculpture, 2D and 3D shapes, using natural materials, as well as speaking, listening and developing team work and social skills. ${ }^{39}$ As noted by the Forestry Commission with regards to the Stour Valley Arts, "children's learning is enhanced hugely through working closely with artists in the natural forest environment". ${ }^{40}$

Whether in connection with social forestry or not, there is no denying that arts organisations are increasingly interested in working with the Forestry Commission on projects related with conservation, forestry, climate change, etc.

The arts also serve to question the place of wood, trees and the natural environment in people's lives. Artists using sculpture and other installations to explore the wider relationship to the environment is a recent, fast-growing trend. This approach of the arts as mediators between nature and mankind lies at the basis of the creation of a very original educational charity. Born in 2006 of the imagination of a previous gallery director, the Centre for the Contemporary Art and the natural World (CCANW) is a pioneering partnership with the Forestry Commission at Haldon Forest in Devon. On top of the means already alluded to, it proposes an exploration, through artistic means, of " our place within Nature through the Arts" and of the meaning of sustainable development. ${ }^{41}$ It aims at exploring forests "as sources of renewable and sustainable fuel and as sources of emotions and cultural resonances and aesthetic pleasure".42 From the outset, CCANW was recognised as the only organisation in Britain with a permanent centre addressing people's evolving place within nature through the arts. Arts Council England South West, and its predecessor South West Arts described it as "one of a small number of genuinely visionary projects being developed in the region, with a strong artistic concept at its core", "a unique venture in its ambition to bring together the contemporary arts and the natural sciences in imaginative and exciting ways". ${ }^{43}$

The driving philosophy of CCANW takes the terms "nature" and "art" in their widest sense: art with an environmental or social conscience; eco-architecture; eco-design; art that interacts with science/scientists and with the landscape; and art that engages with and reflects upon contemporary issues (e.g. the technical, social and cultural responses to the disastrous outbreak of foot-and-mouth disease on farms, or the genetic modification of crops), while supporting a wider social sense of care for the natural environment. 
This brief review of artistic practices taking place in Forestry Commission forests shows that on top of producing art that is of value per se, active involvement in the arts in woodland settings is making an active contribution to various social agendas, as well as fostering the development of care for the natural environment and a reflection on contemporary issues and on the relations between the arts and sciences.

\section{Crisis : What crisis ?}

It is against this backdrop that, in October 2010, the Public Bodies Bill, published by the Cabinet Office, cleared the way for the privatisation of much of the Forestry Commission's land in England.

\section{The Forestry Commission and the Conservative government}

On 27 January 2011, the government unveiled its plans: the Department for Environment, Food and Rural Affairs (DEFRA) proposed

to lease woodland to private sector operators and hand over control of England's "heritage forests" to charitable trusts. The coalition is already committed to taking 15 per cent of the public forest estate out of state control, generating up to $£ 100 \mathrm{~m}$ of receipts, but is now trying to decide on the future of the remaining 85 per cent still owned by the Commission. ${ }^{44}$

The government's argument, repeatedly voiced by its Environment Secretary, was that private organisations or charities were much better placed than the public sector to manage forests for the benefit of commercial forestry, social forestry and biodiversity. Under cover of boosting public control and promoting the Big Society by putting conservation in the hands of local communities and charities, ${ }^{45}$ this was clearly an attempt to find means of saving on a sector which had never been profitable since its creation in 1919 and which had already escaped privatisation by a hair's breadth in the 1980s and 1990s.

DEFRA insisted "that a transfer to private ownership [would] not lead to forests being felled and the land built upon" ${ }^{\prime 4}$, since existing planning restrictions would remain in place, and considered as unrealistic opponents' view that "the controversial decision will pave the way for a huge expansion in the number of Center Parcs-style holiday villages, golf courses, adventure sites and commercial logging operations throughout Britain as land is sold to private companies".47

\section{The public's reaction: a vindication of multi-purpose state forestry}

The government's plan was expected and public reaction was rapid. It hinged on two main arguments: the privatisation of a public asset and the question of services. Indeed, the consultation document launched by DEFRA, supposed to last for twelve weeks, invited

views on the mixed-model approach, the criteria for deciding which parts of the estate fit within each model, the principles guiding each model, the safeguards for providing public benefits, and alternative approaches. We also invite views on the implications for the future role of the Forestry Commission in England of these proposals. $^{48}$

In other words, the government was inviting comments on how to dispose of the Forestry Commission lands without asking first whether the public wanted them disposed of. The numerous public demonstrations, exchanges on blogs and press articles pointed out the 
project's main defect: it relied on the privatisation of the forests for the benefit of the public while never demonstrating how the public sector had failed, leading to the oftheard comment that: if it ain't broke, don't fix it. Opinion polls, as well as answers to the DEFRA consultation, suggested that an overwhelming proportion of the public (more than $80 \%$ ) did not want the woodlands to be privatised, ${ }^{49}$ hence a deadlock and public uproar which lasted for three weeks, until the consultation was cancelled on 17 February 2011 and the forestry clauses removed from the Public Bodies Bill. Interestingly, a similar proposal in Scotland in 2009 had equally attracted opposition after the proposal of leasing some of the forests there as part of the Scottish Climate Change Bill Consultation.

Analysing the responses by the 354 English local authorities and 7301 private individuals who answered the consultation, it comes out clearly that English people feel the State has custody of the forests and should keep them in perpetuity for future generations: forests belong to the people, not to the Government, who therefore has no right to sell what is a public asset. ${ }^{50}$

Then, the question of the services provided to the public by state forests was left pending under the proposed arrangements, beginning with access, which caused great concern and loomed large in the respondents' comments in the consultation. ${ }^{51}$ Under private regime, depending on status, some owners might not be held by the Countryside and Rights of Way Act 2000, and even where they were, the latter does not include the obligation to maintain the footpaths or stiles, to accept bicycles or horse riders or to provide car parks and other facilities for the public.

In the consultation, many respondents also argued that more should be done to protect public benefits at large. ${ }^{52}$ These non-market benefits, or cultural ecosystem services, present in state forests since the 1967 Forestry Act $^{53}$ and even more so since the creation of Community Forests around big cities in the early 1990s, are guaranteed by the State, but the private sector would be under no such obligation. As the report of the Independent Panel pointed out,

the relatively recent shift towards the delivery of wide-ranging public benefits, including access and nature conservation (the value of which, as estimated by the National ecosystem Assessment, far exceeds that of the timber), is out of step with this model. The value of these benefits is not captured on the balance sheet..$^{54}$

The consultation did not mention culture or the arts, but many responses to open questions stressed the importance of the cultural values of forests as well as their value for health, education and well- being. ${ }^{55}$ It is obvious that the public benefits of state forests, amongst which artistic pursuits, rank high in the public's priorities and in the causes for anger in all the demonstrations that occurred at the beginning of 2011 under the slogan 'Hands off our forest' or 'Save our forest'. There are instances of private bodies funding the arts in forests (e.g. Esso in the New Forest, Barclays Bank in the Red Rose Community Forest, Tilhill Forestry in Westonbirt Arboretum), ${ }^{56}$ but such funding is unreliable and it is obvious that the reform would have dealt a major blow to the development of arts programmes in forests: as has been shown above, it is in the public forestry sector that artistic practices have been developed and there is strong reason to believe that forests under private or charitable governance would have little interest and/or no money to commission artworks.

The cost to the taxpayer of such a wide array of benefits provided by the Forestry Commission (barely 30p a year per taxpayer) made the projected reform look like a bad bargain indeed, especially as " $70 \%$ of the costs of managing public forests in England are 
covered by commercial revenue" ${ }^{57}$ Last but not least, with this plan, the government cut itself off from its electoral basis in the south and the centre of England (the so-called 'Tory backwoodbenchers'), who did not recognise their interests in the announced measures.

These arguments account for the failure of the projected reform and explain why the online Save Our Forests petition launched by pressure group 38 Degrees $^{58}$ gathered half a million signatures in just a few weeks, while campaigns were organised at local and national level by ad hoc groups of the public (Save our Woods) or professionals (Save our Forests), as well as blogs (Save Britain's Forests).

The Forestry Commission has had a lot of opponents throughout its history. The immense support it experienced on the occasion of its aborted privatisation in 2011 contributed to strengthen its legitimacy as a public operator versus the private sector, especially regarding its non-commercial missions. The fact that it is the largest single destination for countryside visits found a resounding echo in public support. Opposition can also be read as support to the cultural, rather than the financial, logic, in a period of crisis.

In March 2011 the Government appointed an independent panel of experts, headed by the Bishop of Liverpool, with the remit of examining forestry policy in England. Their call for views attracted more than 42,000 responses, the analysis of which shows an explicit support for forests as places of culture, the arts, health and identity. The panel published its Progress Report on 8 December 2011, while the final report to the government, with recommendations, was made in spring 2012.

The 2011 Forestry Commission crisis represented an embarrassing moment for a government who claimed to be the greenest the country had ever had, and the coalition government had to back down, as David Cameron was faced with the prospect of a crisis akin to Margaret Thatcher's Poll Tax. This fiasco points to the ambivalent perceptions of the function of forests in 21st century England: adjustment tools for the Government, as they have recurrently been throughout history, but also irreplaceable places fulfilling social and cultural needs. It can also be interpreted as a landmark in the recognition of the Forestry Commission as one of the largest networks of environmental arts in England.

\section{Conclusion}

It can be argued that, like many other organisations, the Forestry Commission has over the last decades jumped on the cultural and artistic bandwagon to save its life in the face of economic unprofitability. However, there is no denying that woodlands have entertained very close links with national identity and culture throughout history. Comments such as "the forests have been with us and protected since Magna Carta", made during the public consultation, reflect a certain perception of national history, identity as well as of the public realm. Even if it does so in an unexpected form - unexpected, that is, for its founders in 1919 - there is no doubt that the Forestry Commission continues to weave identity relationships between the English and their environment, and that the arts contribute both to this relationship and to a certain definition of what a public service is all about. As additional proof of it, at the end of 2016, a new partnership was created between Arts Council England and Forestry Commission England: "Forest Art Works", "to support achieving great art for everyone in England's public forests". ${ }^{59}$ 
As early as 1996, in a symposium on the non-market benefits of forestry, the question was being asked "can non-market values save the world's forests?". ${ }^{60}$ It looks as though in England, and in Western Europe generally, ${ }^{61}$ the answer is a resounding 'yes'. The failed privatisation of the Forestry Commission in 2011 demonstrated that social forestry, including its artistic dimensions, has progressively come to the fore of what forestry means today. Although the country has never been self-sufficient in wood products and State forests have never been profitable (which was the sole argument put forward by the Government to justify their privatisation), the forests managed by the Forestry Commission have however contributed to society in many other ways over the past thirty years, within the framework of multi-purpose forestry. As the report of the panel puts it, "Forestry, as an activity, has the potential to be a great example of a 'win-win- win' for people, the environment and the economy". ${ }^{62}$

I am very grateful to the people who kindly took the time to answer my questions on various aspects of the arts, woodlands and the Forestry Commission:

Clive Adams, founder and director of the Centre for Contemporary Arts and the Natural World, Haldon Forest (Somerset)

Clive Davies, previously director of the North East Community Forest, consultant advisor in urban forestry

Anna Lawrence, Head of the Social and Economic Research Group, Forestry Commission

Dave Pritchard, Artist and Consultant, UK Arts and Environment Network

Hayley Skipper, Arts Curator, Grizedale Forest (Cumbria), Forestry Commission

Sylvie Nail est professeure de civilisation britannique à l'Université de Nantes, et chercheuse au CRINI (EA 1162). Ses recherches portent sur les relations entre politiques publiques, citadins et nature en Europe et dans les Amériques, ainsi que sur les villes face aux défis du 21ème siècle.

\section{BIBLIOGRAPHY}

Arts Council, The Arts, Health and Well-Being (London, Arts Council, 2007).

Black, Richard, “Government vows protection in forest plan”, BBC News, 27 January 2011.

Clark, David, "Our Forests are our Forests”, The Guardian, 16 November 2010.

Corbin, Alain, La douceur de l'ombre (Paris, Fayard, 2013).

De Groot, R. and Ramakrishnan, P., "Cultural and Amenity Services” (Chapter 17), in Millennium Ecosystem Assessment, Ecosystems and Human Well-Being: Current State and Trends Assessment. Findings of the Condition and Trends Working Group (Washington D.C., Island Press, 2005, pp. 455-476. DEFRA, A Strategy for England's Trees, Woods and Forests (London, DEFRA, 2007).

DEFRA, “The Future of Forestry in England”, DEFRA News, 17 February 2011. https://www.gov.uk/ government/news/the-future-of-forestry-in-england. Last accessed 6 January 2018.

DEFRA, Independent Panel on Forestry Progress Report (London, DEFRA, December 2011). 
DEFRA, Forestry Commission, England, The Future of the Public Forest Estate in England: A Public Consultation (London: DEFRA, 2011).

DEFRA et. al,.UK National Ecosystem Assessment (Cambridge, UNEP WCMC, 2011).

Department of Health, Arts Council, A Prospectus for Arts and Health (London, Arts Council England, 2007).

Edwards, David, Social and Cultural Values Associated with European Forests in Relation to Key Indicators of Sustainability, EFORWOOD D2.3.1 (Edinburgh, Forest Research, 2006).

Farcy, Christine, Nail, Sylvie et. al., "Toward a social representation of forest by Western urbanized societies", in Farcy, Christine (ed.), Forestry in the Midst of Social Change (Boca Raton (Florida), CRC Press, 2018 (in press)).

Forestry Commission, England, Public Opinion of Forestry 2011, UK and England (Edinburgh, Forestry Commission, 2011).

Forestry Commission, England, Stour Valley Arts, http://www.forestry.gov.uk/pdf/se-casestudiesstourvalleyarts.pdf/\$FILE/se-casestudies-stourvalleyarts.pdf, last accessed 10 January 2018.

Forestry Commission, England, Forest Art Works, 29 September 2016. https://

www.forestry.gov.uk/forestartworks. Last accessed 11 January 2018.

Forestry Commission, England, Forestry Statistics 2017 (Edinburgh, IFOS Statistics, 2017).

Harrell, Eben, “Will Britain sell off its public forests?”, Time, 25 October 2010. http:// science.time.com/2010/10/25/will-britain-sell-off-its-public-forests/ Last accessed 5 January 2018.

Jansen, Mark, “England's controversial forest sale could attract biofuel energy companies”, The Ecologist, 8 December 2010, http://www.theecologist.org/News/news_analysis/691054/ englands_controversial_forest_sale_could_attract_biofuel_energy_companies.html, last accessed 5 January 2018.

Lawrence, Anna and Jollands, Matthew, The Future of the Public Forest Estate in England. Analysis of Responses to the Curtailed Public Consultation January-February 2011, Final Report (Farnham, Forest Research, 2011).

Millenium Ecosystem Assessment, Ecosystems and Human Well-being: Synthesis (Washington D.C., Island Press, 2005).

Ministerial Conference on the Protections of Forests in Europe, Forestry and our Cultural Heritage. Report of seminar, 13-15 June 2005, Warsaw, MCPFE. http://www.foresteurope.org/filestore/ foresteurope/Meetings/2005/sems/Report_Sweden.pdf, last accessed 10 January 2018.

Nail, Sylvie, Forest Policies and Social Change in England (New York, Springer, 2008).

Nichols, Will, “Defra forestry plans revealed”, Business Green, 27 January 2011, https:// www.businessgreen.com/bg/news/1940013/defra-forestry-plans-revealed, last accessed 11 January 2018.

O'Brien, Elizabeth, "Social and cultural values of trees and woodlands in northwest and southeast England", Forest Snow and Landscape Research 79:1/2 (2005), pp. 169-184.

O'Brien, Liz and Morris, Jake, "Well-being for all? The social distribution of benefits gained from woodlands and forests in Britain”, Local Environment 19:4 (2014), pp. 356-383.

Pearce, D., "Can non-market values save the world's forests?" in Stewart Roper, C. and Park, A. (eds), The Living Forest: Non-market Benefits of Forestry. Proceedings of an international symposium on 
non-market benefits of forestry held in Edinburgh, 24-28 June 1996, organised by the Forestry Commission (London: The Stationery Office, 1999), pp 4-16.

Pritchard, David, Natural Horizons: A review of the partnership at Haldon Forest Park between the Forestry Commission and the Centre for Contemporary Art \& the Natural World. Consultant report for FC and CCANW, n.p., 2010.

Pritchard, David, Artistic Licence: A review of the Forestry Commission's involvements in the arts, and options for the future, Consultant report for the Forestry Commission; in association with the Centre for Contemporary Art and the Natural World, 2008.

Rival, Laura (ed.), The Social Life of trees. Anthropological Perspectives on Tree Symbolism (Oxford, Berg, 1998).

UNECE/ FAO, UNESCO, Ministerial Conference on the Protection of Forests in Europe Liaison Unit, Indicators for Sustainable Forest Management: United Kingdom Reporting Form 6.11: Cultural and spiritual values, (Vienna, UNESCO, 2011).

Van Der Zee, Bibi, “England's forests: a brief history of trees", The Guardian, Saturday 27 July 2013.

\section{NOTES}

1. Bibi Van Der Zee, "England's forests: a brief history of trees", The Guardian, 27 July 2013.

2. Laura Rival (ed.), The Social Life of Trees. Anthropological Perspectives on Tree Symbolism (Oxford, Berg, 1998).

3. Sylvie Nail, Forest Policies and Social Change in England (New York, Springer, 2008).

4. Forestry Commission, Forestry Statistics 2017 (Edinburgh, IFOS Statistics, 2017).

5. Christine Farcy, Sylvie Nail et al., "Toward a social representation of forest by Western urbanized societies" in Christine Farcy (ed.), Forestry in the Midst of Social Change (Boca Raton, Fl., CRC Press, 2018 (in press)).

6. Liz O'Brien \& Jake Morris, "Well-being for all? The social distribution of benefits gained from woodlands and forests in Britain", Local Environment 19: 4, 2014, pp. 356-383.

7. Rudolf de Groot \& P. Ramakrishnan, "Cultural and amenity services" in Millennium Ecosystem Assessment, Ecosystems and Human Well-Being: Current State and Trends Assessment. Findings of the Condition and Trends Working Group (Washington D.C., Island Press, 2005), p. 465.

8. DEFRA, Independent Panel on Forestry Progress Report (London, Defra, 2011), p. 15.

9. Ibid.., p. 15.

10. UNECE/ FAO, UNESCO, Ministerial Conference on the Protection of Forests in Europe Liaison Unit, Indicators for Sustainable Forest Management, United Kingdom Reporting Form 6.11: Cultural and spiritual values (Vienna, UNESCO, 2011), p. 3. http://www.forestry.gov.uk/pdf/soefind6.11.pdf/ \$FILE/soefind6.11.pdf. Last accessed 5 January 2018.

11. Millennium Ecosystem Assessment, Ecosystems and Human Well-being: Synthesis (Washington D.C., Island Press, 2005), p. 5. The UK National ecosystem Assessment was published by UNEPWCMC in 2011. http://uknea.unep-wcmc.org/resources/tabid/82/Default.aspx

12. See for example in the UK, Parliamentary Office of Science and Technology, "Ecosystem Services", Postnote 281, March 2007, p. 1. POST is an office of both Houses of Parliament, charged with providing independent and balanced analysis of public policy issues related to science and technology.

13. Millennium Ecosystem Assessment, op. cit., p. 9.

14. Alain Corbin, «Tourisme arboricole ", in La Douceur de l'Ombre (Paris, Fayard, 2013), p. 80. See more particularly the first three chapters of the book on this issue. 
15. "General Declaration", Third Ministerial Conference on the Protection of Forests in Europe, 2-4 June 1998, Lisbon/Portugal, http://www.foresteurope.org/docs/MC/MC_lisbon_gral_declaration.pdf, p. 1. Last accessed 6 January 2018.

16. Ministerial Conference on the Protection of Forests in Europe, Forestry and our Cultural Heritage. Report of seminar, 13-15 June 2005, Warsaw, MCPFE. http://www.foresteurope.org/ filestore/foresteurope/Meetings/2005/sems/Report_Sweden.pdf, last accessed 10 January 2018.

17. Parliamentary Office of Science and Technology, "Ecosystem Services", op. cit..

18. Millennium Ecosystem Assessment, op. cit., p. 10.

19. David Pritchard, Artistic Licence: A review of the Forestry Commission's involvements in the arts, and options for the future (2008), p. 5. Available http://ccanw.org.uk/pdf/ Article_Pritchard_License.pdf. Last accessed 20 June 2018.

20. DEFRA, A Strategy for England's Trees, Woods and Forests (London, DEFRA, 2007).

21. Ibid.., p. 4.

22. David Pritchard, Natural Horizons: A Review of the Partnership at Haldon Forest Park between the Forestry Commission and the Centre for Contemporary Art \& the Natural World. Consultant report for FC and CCANW (n.p., 2010), p. 13.

23. David Pritchard, Artistic Licence, op. cit..

24. David Pritchard, Natural Horizons, op. cit., p. 11.

25. Ibid.., p. 12.

26. David Edwards, Social and Cultural Values Associated with European Forests in Relation to Key Indicators of Sustainability, EFORWOOD D2.3.1, Forest Research, 2006, p. 36.

27. E.A. O'Brien, "Social and cultural values of trees and woodlands in northwest and southeast England", Forest Snow and Landscape Research 79: 1/2 (2005), p. 171.

28. Haley Skipper, pers. com.

29. David Pritchard, Artistic Licence, op. cit., p. 25

30. Haley Skipper, pers. com.

31. Forestry Commission England, Stour Valley Arts, http://www.forestry.gov.uk/pdf/secasestudies-stourvalleyarts.pdf/\$FILE/se-casestudies-stourvalleyarts.pdf, last accessed 10 January 2018.

32. David Pritchard, Artistic Licence, op. cit., p. 25.

33. The Forestry Commission is the largest provider of outdoor recreation in Britain and receives over 100 million visits to its woodlands each year, Forestry Commission, England, "The Forestry Commission", https://www.forestry.gov.uk/forestry/infd-76zl3l, last accessed 4 January 2018.

34. DEFRA, Independent Panel on Forestry Progress Report, op. cit., p. 15.

35. Arts Council, The Arts, Health and Well-Being (London, Arts Council, 2007), p. 2.

36. Department of Health, Arts Council, A Prospectus for Arts and Health (London, Arts Council England, 2007), p. 2.

37. The most common activity undertaken by those who visited woodland was exercise ( $66 \%$ in the UK and 65\% in England), according to Forestry Commission, Public Opinion of Forestry. 2011, UK and England (Edinburgh, Forestry Commission, 2011), p. 4.

38. E.A. O'Brien, "Social and cultural values of trees and woodlands in northwest and southeast England", op. cit..

39. Sylvie Nail, Forest Policies and Social Change in England, op. cit., pp. 190-199.

40. Forestry Commission, Stour Valley Arts, op. cit..

41. David Pritchard, Natural Horizons, op. cit., p. 8.

42. Clive Adams, pers. com.

43. David Pritchard, Natural Horizons, op. cit., p. 9.

44. Will Nichols, "Defra forestry plans revealed", Business Green, 27 January 2011, https:// www.businessgreen.com/bg/news/1940013/defra-forestry-plans-revealed, last accessed 11 January 2018. 
45. Richard Black, “Government vows protection in forest plan”, BBC News, 27 January 2011: "It's time for the government to step back and allow those who are most involved with England's woodlands to play a much greater role in their future... and we will make sure that public access is maintained and biodiversity protected."

46. Mark Jansen, "England's controversial forest sale could attract biofuel energy companies", The Ecologist, 8 December 2010. https://theecologist.org/2010/dec/08/englands-controversialforest-sale-could-attract-biofuel-energy-companies. Last accessed 2 January 2018.

47. Eben Harrell, “Will Britain sell off its public forests?", Time, 25 October 2010. http:// science.time.com/2010/10/25/will-britain-sell-off-its-public-forests/ L ast accessed 5 January 2018.

48. DEFRA, Forestry Commission, The Future of the Public Forest Estate in England. A Public Consultation (London, DEFRA, 2011), p. 8.

49. In the words of one respondent to the consultation, "As a citizen of the United Kingdom, and therefore a shareholder in these publicly owned forests, I do not want them sold at all. They cost me approximately 20p per year in tax, and frankly if they cost me a hundred times that, they'd be a bargain", Anna Lawrence and Matthew Jollands, The Future of the Public Forest Estate in England. Analysis of Responses to the Suspended Public Consultation, (Alice Holt, Forest Research, 2011), p. 52.

50. Ibid, p. 71.

51. Ibid.., p. 6.

52. Ibid.., p. 9.

53. The Forestry Act 1967, which repealed and updated the Acts of 1919, 1945 and 1951, made it an obligation for the Forestry Commission to provide for leisure needs in its forests. Sylvie Nail, Forest Policies and Social Change in England, op. cit., p. 72.

54. DEFRA, Independent Panel on Forestry Progress Report, op. cit., p. 25.

55. Anna Lawrence and Matthew Jollands, The Future of the Public Forest Estate in England., op. cit., pp. 8 \& 28 .

56. David Pritchard, Artistic Licence, op. cit., p. 34.

57. David Clark, “Our Forests are our Forests”, The Guardian, 16 November 2010.

58. This British not-for-profit political-activism organization is so called, because 38 degrees is the angle at which an avalanche happens; the idea is to spur its members to create an avalanche for change.

59. Forestry Commission England, Forest Art Works, 29 September 2016. https:// www.forestry.gov.uk/forestartworks. Last accessed 11 January 2018.

60. D. Pearce, "Can non-market values save the world's forests?" in C. Stewart Roper and A. Park (eds.), The Living Forest: Non-Market Benefits of Forestry. Proceedings of an international symposium on non-market benefits of forestry held in Edinburgh, 24-28 June 1996, organised by the Forestry Commission (London, The Stationery Office, 1999), pp 4-16.

61. Christine, Farcy, Sylvie Nail et al., "Toward a social representation of forest by Western urbanized societies", op. cit..

62. DEFRA, Independent Panel on Forestry Progress Report, op. cit., p. 6. 


\section{ABSTRACTS}

In January 2011, the projected privatisation of the lands managed by the Forestry Commission in England led to several weeks of protests, as a result of which the coalition government backed down. This episode points to the ambivalent perceptions of the function of forests in 21st century England: adjustment tools for the Government, but also irreplaceable places fulfilling social needs. Within these, the cultural services occupy a growing place and the arts constitute essential components of multipurpose forestry, more often than not in relation to public policies concerning health, education, environment, etc. It is this unsung aspect of today's forestry that this article will explore, so as to understand how and why the arts are summoned in wooded spaces, the cultural dimensions of forests and what English people would lose out to a privatisation that they made clear they were hostile to anyway.

En janvier 2011, la privatisation envisagée des terrains gérés par la Forestry Commission en Angleterre conduisit à plusieurs semaines de protestations, au terme desquelles le gouvernement de coalition fit machine arrière. Cet épisode témoigne de l'ambivalence dans la perception des forêts dans l'Angleterre $\mathrm{du} 21^{\mathrm{e}}$ siècle: variables d'ajustement pour le gouvernement, mais également lieux irremplaçables pour combler des besoins sociaux. Au nombre de ceux-ci, les services culturels occupent une place croissante et les arts constituent des composants essentiels de la multifonctionnalité forestière, le plus souvent en lien avec les politiques publiques de santé, d'éducation, d'environnement, etc. C'est cet aspect méconnu que cet article explore, afin de comprendre comment et pourquoi les arts sont mobilisés dans les espaces boisés, ce à quoi ils renvoient en termes culturels et ce que les Anglais perdraient à une privatisation, à laquelle ils ont de toute façon clairement manifesté leur hostilité.

\section{INDEX}

Mots-clés: Forestry Commission, services culturels des forêts, arts, privatisation

Keywords: Forestry Commission, cultural services of forestry, arts, privatisation 